WIESŁAW PARTYKA* - LUBLIN

\title{
BANK POBOŻNY W ZAMOŚCIU W XVII-XVIII WIEKU
}

Kanclerz Jan Zamoyski budując swoją potęgę i majątek, czego ukoronowaniem było m.in. założenie miasta Zamościa (1580) i Ordynacji Zamojskiej (1589), nie zapominał również o swoich poddanych, szczególnie tych, którzy potrzebowali pomocy ze względu na swój wiek, stan zdrowia, sytuację finansową czy inne przyczyny. To właśnie w Zamościu, który stał się siedzibą rodową oraz centrum zarządzania rozległym majątkiem, najlepiej widoczna była polityka Jana Zamoyskiego i jego następców w stosunku do dóbr i poddanych. Zamość, idealne miasto epoki Odrodzenia ${ }^{1}$ był miejscem, gdzie obok tak prestiżowych instytucji, jakimi były m.in. kolegiata czy Akademia Zamojska, powstawało szereg dzieł o charakterze dobroczynnym i opiekuńczym. Były to m.in. szpitale-przytułki, bursy dla ubogiej uczącej się młodzieży, fundacje stypendialne, system zapomóg itp.

Jedną z form wspierania poddanych przez rodzinę Zamoyskich była instytucja o nazwie Bank Pobożny lub inaczej Mons Pietatis. Była to kasa zapomogowo-pożyczkowa mająca na celu wspieranie przede wszystkim rzemieślników i mieszczan w ciężkich czasach (np. klęski żywiołowe, choroba), chroniąca ich tym samym przed materialną ruiną i wyzyskiem ze strony lichwiarzy. Tego typu instytucje zaczęły powstawać w Polsce od końca XVI wieku za sprawą jezuity Piotra Skargi, który założył pierwszy Bank Pobożny w Krakowie na wzór instytucji działających za granica, szczególnie we Włoszech².

Bank Pobożny w Zamościu założył kanclerz Jan Zamoyski przywilejem fundacyjnym wydanym w obozie nad Gowią dnia 16 października 1601 roku$^{3}$. An-

${ }^{*}$ Wiesław Partyka - dr historii, asystent w Katedrze Historii Opieki Społecznej, Instytut Pedagogiki, Wydział Nauk Społecznych KUL.

${ }^{1}$ W. Kalinowski, Zamość idealne miasto Renesansu, w: Czterysta lat Zamościa, red. J. Kowalczyk, Wrocław 1983, s. 87-93.

2 J. Tazbir, Piotr Skarga. Szermierz kontrreformacji, Warszawa 1983, s. 197-199; B. Kumor, Bank pobożny, w: Encyklopedia Katolicka, t. 1, red. F. Gryglewicz, R. Łukaszyk, Z. Sułowski, Lublin 1985, k.1305-1306; Z. Budzyński, Dzieje opieki społecznej w Ziemi Przemyskiej i Sanockiej (XV-XVIII w.), Przemyśl 1987, s. 152.

${ }^{3}$ Archiwum Archidiecezjalne w Lublinie (dalej: AAL), Rep 60 A 152, Acta Visitationis Gene- 
drzej Kędziora i Franciszek Stopniak jako datę założenia tej instytucji podają 18 października, powtarzając ją najprawdopodobniej za Ambrożym Wadowskim ${ }^{4}$. Nie wiadomo, czy pobudką do założenia przez Zamoyskiego Banku Pobożnego była znana w całym kraju działalność Piotra Skargi, czy też może osobiście zetknął się on z tego typu instytucjami podczas swoich studiów we Włoszech. Na uruchomienie Mons Pietatis kanclerz przeznaczył kapitał w wysokości 10 tys. zł, a kuratorami tej instytucji ustanowił dziekana-infułata, scholastyka oraz rajców zamojskich $^{5}$. Jednak bezpośredni nadzór nad kasą Banku Pobożnego zostawił sobie, zobowiązując zarządców do składania mu rocznych sprawozdań finansowych $^{6}$. Bank miał udzielać pożyczek pod zastaw uczącej się młodzieży i rzemieślnikom na okres co najwyżej 1 roku na niski procent, a wysokość udzielanego kredytu nie mogła przekraczać $100 \mathrm{zł}^{7}$. Dochody z pobieranych procentów miały być przeznaczane na potrzeby niezamożnej, uczącej się młodzieży pochodzącej ze wszystkich miast ordynackich ${ }^{8}$.

Nie od razu Bank Pobożny rozpoczął swoją działalność i nie od razu też pieniądze zapisane przez fundatora znalazły się w jego dyspozycji. Pierwsze 5 tys. zł Zamoyski zobowiązał się wpłacić po trzech latach od wystawienia dokumentu, a kolejne 5 tys. mieli wpłacić wykonawcy jego testamentu9. Mimo takiego zapisu jeszcze przez długi czas Bank Pobożny nie mógł rozpocząć swojej działalności. Nie dokonało się to ani za życia fundatora (zm. 1605), ani też za życia jego syna Tomasza (zm. 1638) ${ }^{10}$. Być może opieszałość w uruchomieniu tej instytucji

ralis Omnium Ecclesiarum Dioecesis Chetmensis Suam Ipsem et Illustrissimus Excellentissimus et Reverendissimus Dominus Dominus Christophorum in Stupow Szembek Dei et Apostolicae Sedis Gratia Episcopus Chetmensis Praepositus Generalis Miechoviensis in sua propria Persona. Anno Domini 1714 die 1ma Mensis 7bris ab Ecclesia Parochiali Gorzkowiensi in choavit [...] Anno Domini 1717 in Ecclesia Praepositurali Skierbieszoviensis feliciter terminavit diebus Prima et Secunda Mensis Julij. [...] Perillustris et Admodum Reverendi Domini Michaelis in Piechowicz Piechowski Ecclesiarum Cathedralis Chetmensis et Collegiatae Scarbimirensis Canonici, Causarum Curiae Suae Illustrissimis Celsitudinis Auditoris et Judicis Generalis per me Thomam Andreas Koluszowski Publicum et Suae Illustrissimus Celsitudinis atque Actorum praesentis Visitationis assumptum Notarium conscripta Anno quo Deus Factus Homo Visitavit Nos Oriens exalto 1714, s. 380v-382; AAL, Rep 60 A 154, Acta visitationis 1726-1729, s. 314v; Zbiór dokumentów Kolegiaty i Kapituty Zamojskiej, wyd. B. Kumor, Lublin 1974, s. 32-34; A. Tarnawski, Działalność gospodarcza Jana Zamoyskiego, kanclerza i hetmana wielkiego koronnego (1572-1605), Lwów 1935, s. 397.

${ }^{4}$ Wiadomości o profesorach Akademii Zamojskiej, wyd. J. A. Wadowski, Warszawa 1899-1900, s. 103; A. Kędziora, Encyklopedia miasta Zamościa, Chełm 2000, s. 33; F. Stopniak, Dzieje Kapituty Zamojskiej, Lublin 1962, s. 161.

${ }^{5}$ AAL, Rep 60 A 152, Acta Visitationis, s. 381; Wiadomości o profesorach, s. 89; Archiwum Państwowe w Lublinie (dalej: APL), sygn. 4386, Opisanie statystyczno-historyczne dóbr Ordynacji Zamoyskiej przez Mikołaja Stworzyńskiego archiwistę 1834, s. 68; Tarnawski, Działalność gos-podarcza, s. 397-398; Stopniak, Dzieje Kapituly, s. 161.

${ }^{6}$ Tarnawski, Działalność gospodarcza, s. 398; Stopniak, Dzieje Kapituły, s. 161.

${ }^{7}$ Tarnawski, Działalność gospodarcza, s. 398.

${ }^{8}$ Tamże.

${ }^{9}$ Zbiór dokumentów, s. 32-33.

${ }^{10}$ Tarnawski, Działalność gospodarcza, s. 398. 
z fundacji Jana Zamoyskiego była powodem podjęcia działań w tym zakresie przez ks. Tomasza Dreznera, dziekana-infułata, rektora Akademii Zamojskiej, profesora prawa. Widząc, że fundacja kanclerza nie może dojść do skutku i Bank Pobożny istniał jedynie na papierze, sporządził testament, na mocy którego cały swój majątek przekazał na uruchomienie Mons Pietatis, z którego mieli korzystać wszyscy mieszczanie $\mathrm{z}$ wyjątkiem Żydów ${ }^{11}$. Na kuratorów tego banku wyznaczył Mikołaja Kiślickiego dziekana-infułata, Sebastiana Siekanowicza profesora prawa, Wojciecha Mordolphusa pisarza miejskiego ${ }^{12}$. Fundację tę z sumą 5114 zł zatwierdził 17 lipca 1621 roku ordynat Tomasz Zamoyski ${ }^{13}$. Część badaczy twierdzi, że była to instytucja odrębna od fundacji Zamoyskiego z $1601 \mathrm{roku}^{14}$. Źródła miejskie, podobnie jak akta wizytacji kanonicznych i akta kolegiaty zamojskiej, nie zawierają jednak zapisów o funkcjonowaniu w Zamościu dwóch Banków Pobożnych. Większość tych źródeł fundację Dreznera traktuje jako podwyższenie kapitału Banku Pobożnego założonego przez kanclerza ${ }^{15}$. Nie wiadomo do końca, jaki był zamysł ks. Dreznera i czy chciał on utworzyć nową instytucję, czy też chciał w ten sposób uruchomić działalność istniejącego już banku, który ciagle czekał na fundusz, jakim mógłby dysponować. Nawet jeżeli miała to być odrębna instytucja, to przez fakt powierzenia pieczy nad tym bankiem dziekanowi-infułatowi i przedstawicielowi władzy miejskiej - a więc praktycznie w te same ręce, co i fundacja Zamoyskiego - szybko doszło do ich połączenia w jeden Mons Pietatis zamojski. Przez pewien czas w świadomości mieszczan Zamościa istniało przeświadczenie o pewnej odrębności fundacji Dreznera, o czym świadczą zapisy pieniężne $\mathrm{z}$ adnotacją że chodzi tu o ten właśnie Bank Pobożny. Zapisy takie można spotkać pośród innych przeznaczonych na szpital i Bank Pobożny ${ }^{16}$. Ambroży Wadowski uważa, że wizytacja biskupa Szembeka z 1750 roku mówi o Banku Pobożnym Dreznera ${ }^{17}$, jednak jest to chyba niewłaściwa interpretacja, gdyż Drezner występuje tam jedynie jako fundator sumy 5114 zł, obok fundacji Jana Zamoyskiego i innych fundatorów ${ }^{18}$.

Wracając jednak do fundacji Jana Zamoyskiego - w roku 1638 suma 10 tys. zł została potwierdzona i zabezpieczona na dobrach ordynackich, ale nadal instytucja ta nie działała w taki sposób, jak to było w zamyśle jej założyciela. Pieniądze, mimo że przyznane i zabezpieczone, jedynie na krótki czas zostały oddane do

\footnotetext{
${ }^{11}$ AAL, Rep 60 A 158, Decreta Reformationis, s. 2134-2140; Wiadomości o profesorach, s. 103.

12 Wiadomości o profesorach, s. 103.

${ }^{13}$ Tamże; AAL, Rep 60 A 154, Acta visitationis, s. 314v; AAL, Rep 60 A 158, Decreta Reformationis, s. 1795.

${ }^{14}$ Wiadomości o profesorach, s. 103; A. Kędziora, Encyklopedia, s. 33.

${ }^{15}$ AAL, Rep 60 A 154, Acta visitationis, s. 314v; AAL, Rep 60 A 158, Decreta Reformationis, s. 1795; APL, Akta Kolegiaty Zamojskiej (dalej: AKZ), sygn. 158, Mons Pietatis 1712-1809 (1814), s. 13.

${ }^{16} \mathrm{Na}$ Bank Pobożny Dreznera wpłacali m.in.: 1646 rok - Jan Ziętochowski, 50 zł; 1664 Oprzałkowie, 50 zł; 1678 - Piotr Karpik, 200 zł na szpital i Bank Pobożny Dreznera (APL, AKZ, sygn. 10, Sumariusz akt kościoła kolegiackiego w Zamościu i akademii 1645-1795, s. 15-17).

${ }^{17}$ Wiadomości o profesorach, s. 103.

${ }^{18}$ AAL, Rep 60 A 158, Decreta Reformationis, s. 2133.
} 
dyspozycji opiekunów Banku Pobożnego. Już w styczniu 1644 roku za zgodą i pokwitowaniem Jana „Sobiepana” Zamoyskiego, podskarbi Fredro wybrał z banku 10 tys. $z^{19}$. W 1650 roku kwota ta wyliczona została w wydatkach Ordynacji jako dług na niej ciążący ${ }^{20}$. Przez cały ten okres suma kapitałowa zwiększała się poprzez drobne zapisy ${ }^{21}$, aby osiagnać $\mathrm{w} 1688$ roku kwotę 12 tys. $\mathrm{z}^{22}$, z tym że 10 tys. pozostawało nadal „na papierze”.

Rok 1688 był dla działalności Banku Pobożnego bardzo istotny. Wtedy to 16 grudnia ordynat Marcin Zamoyski potwierdził i zabezpieczył sumę 12 tys. zł w kasie zamojskiej, zalecając, aby wypłacać na rzecz banku od każdego złotego 1 grosz rocznego procentu ${ }^{23}$. Mimo tych zapisów nadal nie można było dysponować sumą kapitałową, bo jak stwierdził Marcin Zamoyski, na prośbę dziekana „tęż sumę przy sobie przytrzymał puty, póki Moneta w Polszcze w swojej codziennej waryacji nie uspokoi i nie ustanowi się [...] żeby pobożna intencja Przodka mego i Fundatora [...] aby wiecznie w cale zostawała mieć chciał, przytrzymać obiecałem [...]. A gdy Pan Bóg da, iż Moneta w Koronie przyjdzie do sum perfektum statum, tedy tę sumę montis pietatis dwanaście tysięcy oddać i wyliczyć z skarbu mego każę [...]"24. Nadal więc suma kapitałowa zapisana w 1601 roku nie znajdowała się w dyspozycji banku. Fundacja Dreznera również miała problemy z rozpoczęciem swojej działalności, mimo tego, że ponad 5 tys. zł oraz drobne zapisy dobroczyńców znajdowały się w jej dyspozycji. Jej funkcjonowanie było na tyle niezorganizowane i nieskuteczne, że pod koniec XVII wieku praktycznie zaprzestała działania. Dopiero w roku 1698, na mocy uchwały profesorów Akademii Zamojskiej, przywrócono jej działalność, chcąc poprzez udzielanie kredytów niezamożnej młodzieży zwiększyć frekwencję studentów w podupadającej uczelni ${ }^{25}$. Do takiej inicjatywy przyczyniła się z pewnością Anna z Gnińskich Zamoyska, której na sercu leżało dobro Akademii ${ }^{26}$. Kiedy Bank Pobożny wznowił swoją działalność, zaczęli go wspierać poprzez zapisy zamojscy dziekani-infułaci. Na przełomie XVII i XVIII wieku ks. Wawrzyniec Sikorski wpłacił 1000 zł, w 1721 roku ks. Józef Skocki 200 zł, w 1742 roku ks. Maciej Pawłowicz 500 zł²7.

Kolejnym istotnym problemem negatywnie wpływającym na funkcjonowanie Banku Pobożnego było ściąganie należnych odsetek od dłużników. Świadczą o tym chociażby skargi kierowane przez zarządców tej instytucji do Trybunału

19 Tamże.

${ }^{20}$ AGAD, Archiwum Zamoyskich (dalej: AZ), sygn. 2521, Akta dotyczace generalnych pozycji przychodu i rozchodu oraz stanu kasy Zamoyskich 1601-1752, 1825, s. 145.

${ }^{21}$ Były to zapisy zarówno na Bank Pobożny, jak również na jego prowizora; zob. APL, AKZ, sygn. 10, Sumariusz, s. 15-18.

${ }^{22}$ Tarnawski, Działalność gospodarcza, s. 398-399; Stopniak, Dzieje Kapituły, s. 161.

${ }^{23}$ AAL, Rep 60 A 154, Acta visitationis, s. 314v; AAL, Rep 60 A 158, Decreta Reformationis, S. 1795 .

${ }^{24}$ APL, AKZ, sygn. 1, Jura et fundationes aliaque documenta ad Ecclesiam Collegiatam Zamoscensem pertinentia 1600-1750, s. 48-52.

${ }^{25}$ A. Tarnawski, Działalność gospodarcza, s. 399.

${ }^{26}$ Ludzie i zdarzenia w barokowym Zamościu, oprac. H. Wiśniewska, Lublin 1996, s. 147.

${ }^{27}$ AAL, Rep 60 A 158, Decreta Reformationis, s. 2133; APL, AKZ, sygn. 158, Mons Pietatis, s. 13. 
Zamojskiego ${ }^{28}$. W 1750 roku, w czasie wizytacji banku, określone zostały wymagania w stosunku do kuratorów tej instytucji, w których zawarte zostało m.in. polecenie, aby w przypadku opóźnień ze spłatą zadłużenia natychmiast wszczynać proces sądowy w celu odzyskania wierzytelności ${ }^{29}$. Sporządzono wówczas spis dłużników wraz z wysokością pożyczonej kwoty i określeniem jej zabezpieczenia (zob. tabela 1).

Tabela 1. Spis dłużników Banku Pobożnego z 1750 roku

\begin{tabular}{|c|c|c|c|}
\hline Rok & $\begin{array}{c}\text { Suma } \\
(\mathbf{z l})\end{array}$ & Dłużnik & Rodzaj zabezpieczenia \\
\hline 1 & 2 & 3 & 4 \\
\hline 1673 & 1300 & & na sklepie Bekierowskim \\
\hline 1700 & 300 & Od Krawca przejął Andrzej Zaleski & dom \\
\hline 1700 & 50 & & pusty grunt Krzywdowiczowski \\
\hline 1700 & 50 & & $\begin{array}{l}\text { grunt Lewandowskiego (teraz jest tam } \\
\text { figura) }\end{array}$ \\
\hline 1700 & 50 & Najpierw Halszczanka a teraz Burdziński & dom \\
\hline 1700 & 100 & Stański & grunt Brodzińskiego \\
\hline 1700 & 180 & Misiaczek & kamienica Łyszkiewiczowa \\
\hline 1701 & 100 & Płoszczyński & grunt \\
\hline 1705 & 50 & Andrzej Szyszkiewicz & dom \\
\hline 1706 & 50 & & grunt Oszczoskiego pod Mniszkami \\
\hline 1708 & 50 & Jan Szyszkiewicz & jatka Ganczarska \\
\hline 1710 & 100 & Wit Onymusz & dom Konrada \\
\hline 1710 & 50 & Maykiewiczowa & grunt Czecha Siodlarza \\
\hline 1711 & 100 & Sukcesorowie Jakuba Pipra & folwark \\
\hline 1713 & 100 & Lewicki & grunt \\
\hline 1714 & 100 & & grunt Tumanowicza \\
\hline 1714 & 50 & Kasprowa Lendwoyciakowa & na Podgroblu \\
\hline 1718 & 300 & & na kamienicy Dubinskiego \\
\hline 1718 & 50 & Sukcesorowie Wernerowskich & folwark \\
\hline 1718 & 50 & Po Skrzypkiewiczu przejął Łapiński & \\
\hline 1718 & 54 & Po Leszczyńskim przejął Żyd Leyzor & \\
\hline 1722 & 100 & $\begin{array}{l}\text { Po Sirczyńskiej na pół roku przejął } \\
\text { Klimkiewicz }\end{array}$ & \\
\hline 1724 & 146 & $\dot{Z} y d$ & dobra Jana Gurniewicza \\
\hline 1724 & 36 & Konstancja Czopowa alias Panczyko & grunt \\
\hline 1724 & 100 & & grunt Miklaski \\
\hline 1726 & 100 & & dom Lewkiewiczowski \\
\hline 1728 & 54 & Mikołaj Majowski & \\
\hline 1728 & 200 & & pole Sokołowskiego i Gągolika \\
\hline 1729 & 100 & Po Namulaku przejął Konstanty & dobra \\
\hline 1732 & 100 & Białowolski & pole \\
\hline
\end{tabular}

${ }^{28}$ APL, Akta Miasta Zamościa (dalej: AMZ), sygn. 75, Księgi exaktorskie miasta Zamościa 1709, s. 29.

${ }^{29}$ AAL, Rep 60 A 158, Decreta Reformationis, s. 2143. 


\begin{tabular}{|c|c|c|c|}
\hline 1 & 2 & 3 & 4 \\
\hline 1739 & 72 & Andrzej Maciukiewicz & dobra \\
\hline 1739 & 600 & & kamienica Faruchowiczowskich \\
\hline 1739 & 274 & & dobra Balewiczowskich \\
\hline 1739 & 54 & Malborski & dom \\
\hline 1740 & 300 & Lubecki & kamienica \\
\hline 1741 & 54 & Teresa Buranowa Stosarka & \\
\hline 1741 & 50 & Wilczyński & dom \\
\hline 1742 & 50 & Piotr Skibiński & dom \\
\hline 1742 & 50 & Tabacznik & zniszczone dobra \\
\hline 1742 & 50 & Franciszek Foydanowicz & jatka \\
\hline 1742 & 50 & Józef Sumecki & jatka szewska \\
\hline 1742 & 50 & Mikołaj Jędruszczuk & dobra \\
\hline 1742 & 100 & Kryskoni Doktor & \\
\hline 1742 & 50 & Dmitrukiewicz & jatka szewska \\
\hline 1742 & 100 & Szczepanowska & kamienica \\
\hline 1742 & 50 & Tomasz Maciakiewicz & jatka \\
\hline 1743 & 50 & Mikołaj Żelechowski & dom \\
\hline 1744 & 120 & Jan Rzepczuk & pole \\
\hline 1746 & 100 & Merdumowicz & zniszczone dobra \\
\hline 1748 & 100 & Martymiakowie & pole \\
\hline 1748 & 50 & Bazyli Wysocki & jatka szewska \\
\hline 1748 & 100 & Kowal Jan Chudzicki & dom \\
\hline 1748 & 100 & Małecki & kamienica \\
\hline 1748 & 54 & Małżonkowie Czarneccy & chałupa \\
\hline 1750 & 50 & Dobranscy & kramnice \\
\hline Razem & 6848 & & \\
\hline
\end{tabular}

Źródło: AAL, Rep 60 A 158, Decreta Reformationis Ab Illustrissimo Excellentissimo et Reverendissimo Domino Domino Josepho Eustachio Comite de Stupow Szembek Episcopo Chetmensi Lata, s. 2141-2142.

Ze sporządzonego w 1750 r. wykazu wynika, że w dyspozycji banku było 6814 zł, suma zaś pożyczonych pieniędzy wynosiła 6848 zł. Pożyczki te były oprocentowane na $7 \% \mathrm{w}$ skali roku, co wg wizytacji powinno dawać $476 \mathrm{zł} \mathrm{rocz-}$ nego przychodu, a dawało jedynie około $100 \mathrm{zt}^{30}$. Stąd też zalecenie, aby sądownie ściagać pozostałe należności. W wykazie tym jako dłużnicy występują Żydzi, co było niezgodne z wolą ks. Dreznera, natomiast pożyczone kwoty wahały się od około 50 do $300 \mathrm{zl}$, a w dwóch przypadkach było to nawet $600 \mathrm{i} 1300 \mathrm{zl}$, co sprzeniewierzało się woli Jana Zamoyskiego. Na tym przykładzie widać, że Bank Pobożny w Zamościu działał nie tyle w zgodzie z zaleceniami fundatorów, lecz w oparciu o decyzje wydawane przez jego prowizorów. Warte podkreślenia jest również to, że w 1750 roku zamojski Mons Pietatis nadal nie dysponował kwotą 10 tys. zł zapisaną w 1601 roku. Dopiero za małoletności ordynata Klemensa, około 1760 roku, magistrat zamojski zaczął pobierać od tej kwoty należne procenty,

${ }^{30}$ Tamże, s. 2142. 
przeznaczając je na działalność banku ${ }^{31}$. W 1783 roku prowizor Banku Pobożnego Teodor Pikuziński, pisarz Trybunału Zamojskiego, przedstawiając sprawozdanie z działalności Mons Pietatis, wyliczył już wszystkie sumy kapitałowe, począwszy od 10 tys. ofiarowanych przez Jana Zamoyskiego aż do 500 zł zapisanych przez dziekana Pawłowicza, które dawały łącznie kwotę $18.814 \mathrm{zł}^{32}$. Roczna prowizja od pożyczonych sum powinna według tego sprawozdania przynosić zysk w wysokości aż 4468 zł 9 gr, wydatki zaś Banku wynosiły 3.412 zł 16 gr 1 szeląg $^{33}$. Tak duża suma uzyskana z prowizji jest zaskakująca - może świadczyć o wyższym niż 7\% oprocentowaniu, przynajmniej niektórych pożyczek, albo po prostu o pomyłce prowizora. Wydatki te były przeznaczane zgodnie $\mathrm{z}$ wolą fundatora m.in. na utrzymanie ubogiej młodzieży studiującej w Akademii Zamojskiej. Ankieta urzędowa przeprowadzona również w 1783 roku mówiła o Mons Pietatis ufundowanym przez Ordynację i rozporządzającym kapitałem $25.000 \mathrm{zt}^{34}$. Według tej ankiety pożyczki udzielane były na $3,5 \%$, a nie - jak według wizytacji z 1750 roku - na 7\%. W 1794 roku Bank Pobożny był w posiadaniu części kamienicy Makuckowskich wystawionej przez rząd gubernialny na licytację. Udziały banku $\mathrm{w}$ tej kamienicy wynosiły $1.170 \mathrm{z}^{35}$. Jeżeli zatem zarządcy Mons Pietatis nie wykupili swojej części, to zapewne dług ten przechodził na kolejnego właściciela nieruchomości. Było to dosyć częstą praktyką, o czym świadczy również wykaz dłużników z 1750 roku.

Andrzej Kędziora podaje, że Bank Pobożny w Zamościu działał do końca XVIII wieku ${ }^{36}$. Wprawdzie władze austriackie przejęły fundusze tej instytucji pod koniec XVIII wieku ${ }^{37}$, lecz formalnie zamojski Mons Pietatis nie został rozwiązany. Świadczy o tym chociażby sprawozdanie o stanie zakładów dobroczynnych w guberni lubelskiej za rok 1870, w którym jest mowa o Banku Pobożnym założonym w 1601 roku przez kanclerza Jana Zamoyskiego ${ }^{38}$. W sprawozdaniu tym wyliczono wszystkie wymienione wcześniej fundacje, które wraz z innymi dochodami dawały łączną sumę 5.909 rs. 59 k. Problemem było jednak ustalenie, gdzie te fundusze się znajdują. Można zatem zgodzić się z tezą że Bank Pobożny działał do końca XVIII wieku zgodnie z wolą fundatorów, jednak po przejęciu jego funduszy przez władze zaborcze dalsza jego działalność w dotychczasowej formie nie mogła być kontynuowana.

Należy jeszcze poświęcić nieco uwagi zarządowi Banku Pobożnego. Zgodnie z życzeniem zarówno Jana Zamoyskiego, jak i dziekana Tomasza Dreznera, nad działalnością tej instytucji czuwać mieli jedni z najważniejszych ludzi w mieście. Wywodzili się oni ze środowiska kolegiaty (dziekan-infułat, scholastyk), władz

${ }^{31}$ Wiadomości o profesorach, s. 103.

${ }^{32}$ APL, AKZ, sygn. 158, Mons Pietatis, s. 13.

${ }^{33}$ Tamże.

${ }^{34} \mathrm{~W}$. Tokarz, Galicya w poczq̨tkach ery józefińskiej w świetle ankiety urzędowej z roku 1783, Kraków 1909, s. 337.

${ }^{35}$ APL, AKZ, sygn. 158, Mons Pietatis, s. 23.

${ }^{36}$ A. Kędziora, Encyklopedia, s. 33.

${ }^{37}$ W. Tokarz, Galicya, s. 337.

${ }^{38}$ Mons Pietatis w Zamościu, „Kurier Lubelski”, 11, 1877, nr 33, s. 2. 
miejskich (burmistrz, pisarz), Akademii Zamojskiej (rektor). Kuratorzy Mons Pietatis wybierali spośród swojego grona prowizora, który był zobowiązany do czuwania nad prawidłową działalnością kasy i składania sprawozdań z jej dochodów i wydatków. Wybór na to stanowisko następował w tym samym czasie, co wybór władz miejskich, a więc na początku każdego roku. Nie było wyraźnie określonej reguły ile osób ma piastować ten urząd jednocześnie. Czasami była to jedna osoba, zazwyczaj przedstawiciel władz miejskich, czasami dwie - jedna ze strony miasta, natomiast drugą był dziekan. Zresztą każdorazowy dziekan-infułat pełnił tę funkcję niejako z urzędu i nie musiał być na nią wybierany.

W latach 1646-1654 funkcję prowizora Banku Pobożnego pełnił Jan Getner ${ }^{39}$. W latach 1658-1659 prowizorem był Aleksander Radaszkiewicz, notariusz wójtowski i sędzia Trybunału Zamojskiego ${ }^{40}$. Kolejnym przedstawicielem rady miejskiej na tym stanowisku był Adam Kraśnicki, ławnik zamojski, pełniący funkcję opiekuna banku w latach 1661-1665 ${ }^{41}$. Bazyli Rudomicz, pełniący wielokrotnie funkcję burmistrza, odnotował pod datą 3 stycznia 1671 roku wybór na prowizora banku Sebastiana Łyskiewicza vel Łyszkiewicza ${ }^{42}$. Pełnił on tę funkcję przez rok, gdyż w 1672 roku na stanowisku tym odnotowani zostali Jan Unikowski, dziekaninfułat i Jan Buynowski, ławnik zamojski ${ }^{43}$. W 1673 roku Sebastian Łyszkiewicz ponownie został prowizorem, funkcję tę pełnił wraz z Jakubem Lenartowiczem ${ }^{44}$. Od 1674 roku Łyszkiewicz sprawował tę funkcję już samodzielnie przez wiele kolejnych lat, pełniąc jednocześnie $\mathrm{w}$ tym czasie kilkakrotnie funkcję rajcy miasta Zamościa. W 1684 roku w księdze radzieckiej obok nazwiska Łyszkiewicza ponownie pojawiło się nazwisko dziekana Jana Unikowskiego ${ }^{45}$. Łyszkiewicz oprócz funkcji pełnionych $\mathrm{w}$ radzie miasta oraz wielu kadencji na stanowisku prowizora Mons Pietatis przez wiele lat był także prowizorem szpitala zamojskie$\mathrm{go}^{46}$. W 1687 roku Marcin Zamoyski zapisał mu 300 zł jako pełniącemu urząd prowizora szpitala i Banku Pobożnego ${ }^{47}$. Jako prowizor Mons Pietatis Łyszkiewicz występował jeszcze w latach 1690, 1692-1694 i 169748. W 1691 roku na sta-

${ }^{39}$ APL, AMZ, sygn. 6, Acta consularia Zamoscensia 1643-1654, s. 87v, 127, 159v, 189v, 195v, $201 \mathrm{v}, 211 \mathrm{v}$.

${ }^{40}$ APL, AMZ, sygn. 7, [Księga Radziecka] 1657-1665, s. 70v, 107v.

${ }^{41}$ Tamże, s. 243, 343v, 391v, 434v.

${ }^{42}$ B. Rudomicz, Efemeros czyli diariusz prywatny pisany w Zamościu w latach 1656-1672, Lublin 2002, cz. 2, s. 338.

${ }^{43}$ APL, AMZ, sygn. 8, Acta Consularia Zamoscensia 1672-1685, s.2v.

${ }^{44}$ Tamże, s. 48.

${ }^{45}$ Tamże, s. 515.

${ }^{46}$ APL, AMZ, sygn. 41, [Księga wójtowsko-ławnicza] 1696-1703, s. 195, 457v; APL, AKZ, sygn. 413, Acta Capitulorum Generalium tam Ordinariorum per Pralatus et Canonicus Insignis Collegiata Ecclesia Zamoscensis celebratorum - Volumen I, in quo post Constitutiones Capitulares in compendium redactas - capitula, ab anno 1658 die 29 Aprilis ad annum 1708 diem 16 Aprilis inclusive inveniuntur, s. 258; APL, AMZ, sygn. 42, [Księga wójtowsko-ławnicza] 1704-1711, s. $213 \mathrm{v}-214$.

${ }^{47}$ APL, AKZ, sygn. 10, Sumariusz, s. 16.

${ }^{48}$ APL, AMZ, sygn. 10, [Księga Radziecka] 1690-1692, s. 31, 687; APL, AMZ, sygn. 40, [Księ- 
nowisku tym był wymieniany również inny burmistrz - Jan Wenton ${ }^{49}$. Kolejnym odnotowanym przez źródła miejskie prowizorem był Sebastian Suchecki (pisarz i rajca), pełniący tę funkcję w latach $1710-1711^{50}$. Być może był nim dłużej, jednak na ten temat brak informacji - zachowała się jedynie wzmianka z 1722 roku, mówiąca o nim jako o byłym prowizorze ${ }^{51}$. Podobna informacja na temat byłego prowizora pochodzi z 1732 roku i odnosi się do rajcy Malborskiego ${ }^{52}$. W 1741 roku opiekunem Banku Pobożnego był Płoszczyński ${ }^{53}$, a w 1744 Michał Balejowicz $^{54}$. Przez wiele lat z rzędu funkcję prowizora sprawował Teodor Pikuziński, będący najpierw pisarzem apostolskim, a następnie pisarzem sądów trybunalskich i komisarskich zamku zamojskiego ${ }^{55}$. Po raz pierwszy jako prowizor został wymieniony w 1749 roku, natomiast ostatnia wzmianka o nim na tym stanowisku pochodzi z roku $1763^{56}$. Wielokrotnie funkcję tę pełnił także rajca zamojski Albert Ulitowski $(1765,1768,1769,1772,1776)^{57}$. W międzyczasie (1770) stanowisko to piastował także burmistrz Albert Surdacki ${ }^{58}$. W 1777 roku, po śmierci Alberta Ulitowskiego, w obecności burmistrzów i całej rady miejskiej na funkcję prowizora wybrano Aleksandra Ligajowskiego, prezentowanego na to stanowisko przez dziekana-infułata ${ }^{59}$. Pod koniec XVIII wieku wymieniono jeszcze nazwiska dwu osób piastujących ten urząd. Byli to burmistrz Adam Fiałkowski i ławnik Marcin Koziołkiewicz. Nazwisko Fiałkowskiego jako prowizora zostało wymienione dwukrotnie, w latach 1778 i $1784^{60}$, natomiast Koziołkiewicz został odnotowany na tym stanowisku także w 1784 roku $^{61}$, z tym że przed wyborem Fiałkowskiego, co miało miejsce 15 kwietnia.

Na przykładzie XVII i XVIII-wiecznego składu prowizorów można stwierdzić, że największą rolę w zamojskim Banku Pobożnym pełniły dwie osoby -

ga wójtowsko-ławnicza] 1690-1695, s. 352v, 448v; APL, AMZ, sygn. 11, Acta Consularia Zamoscensia 1694-1698, s. 211.

${ }^{49}$ APL, AMZ, sygn. 10, [Księga Radziecka], s. 513; APL, AMZ, sygn. 40, [Księga wójtowskotawnicza], s. 97.

${ }^{50}$ APL, AMZ, sygn. 42, [Księga wójtowsko-ławnicza], s. 808, 944v.

${ }^{51}$ APL, AMZ, sygn. 44, [Księga wójtowsko-ławnicza] 1721-1734, s. 141.

${ }^{52}$ Tamże, s. 825v.

${ }^{53}$ APL, AMZ, sygn. 46, [Księga wójtowsko-ławnicza] 1740-1744, s. 11v.

${ }^{54}$ APL, AMZ, sygn. 47, Acta advocatialia et scabinalia Zamoscensia 1744-1751, s. 14v.

${ }^{55}$ APL, AMZ, sygn. 48, Acta advocatialia et scabinalia Zamoscensia 1749-1755 - inducta, s. $228 \mathrm{v}$.

${ }^{56}$ Tamże, s. 39v, 130v, 165v, 342, 430, 597v; APL, AMZ, sygn. 49, Liber advocatialis 17561760 , s. 95v, 154v, 408, 482v; APL, AMZ, sygn. 50, Inducta advocatialia 1761-1762, s. 33, $207-$ 207v; APL, AMZ, sygn. 51, Inducta actorum advocatialium 1763-1765, s. 94-94v.

${ }^{57}$ APL, AMZ, sygn. 52, Liber advocatialis seu inducta 1765-1767, s. 7v; APL, AMZ, sygn. 16, [Księa Radziecka] 1767-1774, s. 54v, 132, 418; APL, AMZ, sygn. 17, Acta officii proconsularis Zamoscensis 1775-1778, s. 77v.

${ }^{58}$ APL, AMZ, sygn. 16, [Księga Radziecka], s. 197v.

${ }^{59}$ APL, AMZ, sygn. 17, Acta officii, s. 114v, 125.

${ }^{60}$ APL, AMZ, sygn. 17, Acta officii, s. 143v; APL, AMZ, sygn. 18, Prothocollon officii proconsularis Zamoscensis 1780-1786, s. 268v.

${ }^{61}$ APL, AMZ, sygn. 18, Prothocollon officii, s. 257v-258. 
dziekan-infułat i burmistrz Zamościa. Z jednej strony mieli oni decydujący głos w sprawie wyboru prowizora, a $\mathrm{z}$ drugiej często osobiście sprawowali pieczę nad tą instytucją.

Niewatpliwie instytucja ta, mimo iż nie działała od początku tak, jak to było w zamyśle założyciela, to jednak od momentu uruchomienia zgromadzonych funduszy niosła pomoc wielu mieszkańcom Zamościa, m.in. ubogim studentom Akademii Zamojskiej. Podobne postępowanie magnatów w stosunku do swoich poddanych przez długi czas nie znajdowało w Rzeczypospolitej naśladowców ${ }^{62}$. Dopiero od połowy XVIII wieku niektórzy z nich zaczęli zakładać kasy zapomogowo-pożyczkowe w swoich dobrach. Można tu przywołać przykłady m.in. księżnej Anny Jabłonowskiej, Zofii i Antoniego Lubomirskich czy Pawła Ksawerego Brzostowskiego ${ }^{63}$.

\section{DIE „FROMME BANK” IN ZAMOŚĆ IM 17.- 18. JAHRHUNDERT}

\section{Zusammenfassung}

Die den jeweiligen Ordinatsherren, angefangen mit Kanzler Jan Zamoyski, obliegende Wohlfahrtspflege wurde im 17.-18. Jahrhundert in Zamość von verschiedenen Institutionen ausgeübt. Eine dieser Einrichtungen war die 1601 von Jan Zamoyski gegründete Bank Pobożny („Fromme Bank”). Hierbei handelte es sich um eine Aushilfs- und Darlehenskasse, die die Bürger von Zamość sowie die Studenten der dortigen Akademie unterstützen sollte. Trotz anfänglicher Schwierigkeiten mit dem Beginn der eigentlichen Tätigkeit dieser Institution erfüllte sie, besonders im 18. Jahrhundert, durchaus ihre Rolle und leiste den Bürgeren von Zamość häufige Unterstützung. Von großer Bedeutung für ihr reibungsloses Funktionieren erwiesen sich die mit der Akademie von Zamość und der Stiftskirche verbundenen Kreise sowie die städtischen Behörden. Es waren gerade Vertreter dieser Kreise, die dem Willen des Stifters entsprechend die Rolle von Kuratoren der Frommen Bank übernahmen. Aus ihrem Kreis wählten sie dann die sogenannten Provisoren, die die Bank direkt leiteten und über ihre Tätigkeit Rechenschaft ablegen mussten. Der Grundgedanke bestand in der Gewährung kleinerer und niedrig verzinster Darlehen für den Zeitraum eines Jahre, wobei diese Grundsätze allerdings mit der Zeit gewissen Veränderungen unterlagen. Dank des Engagements zahlreicher Kreise, u.a. der Familie Zamoyski, der Infulaten-Dekane, der Professoren der Akademie und der Stadtverwaltung, überdauerte die Fromme Bank und diente den Bewohnern von Zamość bis zu den Polnischen Teilungen. Daher verdienen sowohl diese Einrichtung, als eine der wenigen dieser Art, die im 17.-18. Jahrhundert in den polnischen Gebieten wirkten, als auch ihr Gründer sowie die späteren Wohltäter unsere Erinnerung und Anerkennung.

\section{Aus dem Polnischen übersetzt von Herbert Ulrich}

${ }^{62}$ W. Tokarz, Galicya, s. 337.

${ }^{63}$ H. Mierzwiński, Kock w okresie reform ks. Anny z Sapiehów Jabłonowskiej, „Szkice Podlaskie", 8, 2000, s. 114; E. Rudzki, Damy polskie XVIII wieku, Warszawa 1997, s. 215; Z. Budzyński, Dzieje opieki, s. 154; E. Rostworowski, Reforma pawłowska Pawła Ksawerego Brzostowskiego (1767-1795), „Przegląd Historyczny”, 44, 1953, z. 1-2, s. 136. 